\title{
Reform on Teaching Modes of the Design Major in Universities Driven by Actual Projects—-Taking Practice Teaching of Product Design as An Example
}

\author{
Shi Bai*, Xin Jin \\ School of Art and Design, Bengbu University, 233000 Bengbu, Anhui, China
}

\begin{abstract}
With the continuous development and upgrades of the design industry, design courses in colleges and universities should advance with the times. In teaching, there are indeed many courses that lose touch with practical applications. Especially in practice teaching, they are disconnected from the designing requirements of the actual projects in the industry. For instance, the contents and modes of teaching deviate from the actual requirements. Based on the contents and teaching modes of practice courses for product design in this paper, the status of teaching is analyzed to strategies for course construction. It aims to promote the practice teaching of product design to better meet the actual demands for the development of the industry and the goals of system.
\end{abstract}

\section{The Teaching Status of Design Major in Colleges and Universities}

Because of the economic development and the transformation of industrial structure in China, the current education reform in colleges and universities is lagging behind, and the talent-training mode and connotation construction of design professionals are not sufficient. Those are as follows. 1. There is a huge gap between the design education and the actual demand for design talents today. It is a new topic for design education that how to recognize and understand the rapid development of society for adapting to the changes of the times. 2. In the process of design education, theoretical courses are important while more attention should be paid to the construction of practical courses. By the impact of new environment, new technologies and new design ideas, reform and development are necessary for designing practice courses. 3. At present, design education is mostly confined to textbooks, theories and surface forms. In fact, it should be combined with professional characteristics and include the extra-school resources, for instance, the actual design projects and cases of enterprises. As a result, design skills are comprehensively improved by the practice of design projects. 4. There is no corresponding platform for school-enterprise cooperation in the process of design teaching in colleges and universities. Attention should be paid to strengthen the information construction, the development of curriculum resources of schoolenterprise cooperation, and the construction of platforms for school-enterprise cooperation. Therefore, students can integrate real design situations and atmospheres into learning, and understand the processes and norms of the design industry. In short, theoretical study is effectively combined with learning by doing.

In terms of design education in colleges and universities, the practical education should be enhanced with emphasis on the authenticity and innovation of subjects. The birthplace of modern design education was Bauhaus-Universitaet Weimar whose teaching system definitely includes the teaching method of "Learning by Doing" [1]. The current models of design education and teaching resources are difficult to meet the dynamic needs of the industry. So it is worth exploring by educators that how to improve the students' abilities of design thinking and practice, and how to make students comprehensively apply what they have learned in actual design projects. At present, the teaching modes of the traditional class should be improved as follows. 1 . Traditional class needs to be extended and transformed. We should take practice courses as the carrier to developing students' abilities of creation and solving problems. It is the aim of the current design education. The practical design projects of enterprises lead the students to more comprehensively and profoundly learn the professional knowledge as well as to broaden their horizons and standardize the design workflow. 2. Design education should be combined with professional characteristics to improve the teaching models. With the project practice of enterprises, students can intuitively understand the advanced design methods and tools today, improve their' specific knowledge of this major. Therefore, student's professional knowledge and skills accelerate to more accurately interface with the needs of the industry, while teaching and research of product design are improved. 3. It is necessary to consider grades and class schedules of the student. In practical teaching, practical design projects that are valuable should be 
arranged in the scientific and flexible manners to solve the problems of unclear teaching methods and single sets of practice so that the actual design projects and curriculum system can be realized closely combined. At the same time, the themes and difficulty of the project are given based on the learning stage of the students, in order to be consistent with the teaching goals. So the students' abilities to apply professional knowledge in actual design projects can be improved.

\section{The Evolution of the Project-driven Teaching Model for Design}

Bauhaus-Universitaet Weimar is the earliest educational institution combining design theories with practice. In the history of modern design education, the establishment of the teaching mode which is "workshop" originated from Bauhaus-Universitaet Weimar. In teaching of 14 years (from 1919 to 1933), it has developed students' professional awareness and reshape ways where they observe the world with a series of rigorous and rational foundation courses for visual training [2]. The 1960s witenesssed the bitth of China's design education which was developed based on traditional art education. The design education system established on the basis of art education was hardly improved from the 1960s to the1980s. With China's reform and opening up, foreign modern design thoughts and education concepts have made greatly influence on China's traditional design education, promoting the rapid development of China's design education since the 1980s [3]. In general, the design education in China remains unclear, and the models and methods of teaching have not kept up with the changes in the social situation with little attention to practice teaching of design. At present, the model of studios has been gradually adopted in the design education by some colleges. Despite its focus on practice training, it has not advanced with the times, unable to fully meet the requirements of the diversified teaching model.

In terms of design education, attention should be paid to the current and potential demands of the society, and the development of teaching models which is driven by the actual projects. We can refer to the professional education mode of the German's Dual System. It means that the entire training process for students is in vocational schools, factories and enterprises, closely combining theoretical teaching in vocational schools with practical teaching in enterprises [4]. Colleges and universities in China can introduce actual projects into the teaching of design practice, so that students can understand how to conduct the standard operation of corporate projects, figure out the real demands of the industry for design talents. It is helpful for students to improve the integrity and achievability of their design works and form the solid foundation for professional quality. Taking the curriculum community as the basic platform to form the relationship between vertical and horizontal ability training, and opening up the comprehensive training link of CDIO engineering education in professional courses (Figure 1). Therefore, the research on teaching reform based on the practical curriculum of product design major in colleges and universities has great significance.

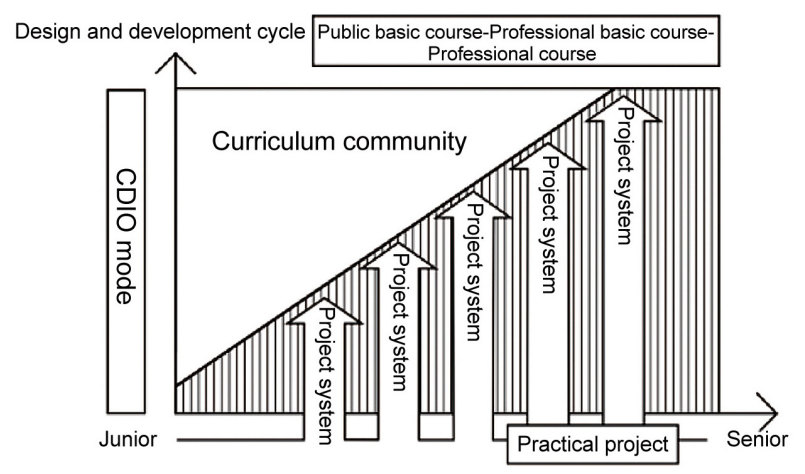

Figure 1. Driving Force for Practical Project Training

Taking Bengbu University's practical curriculum of product design major as an example, the third-year students of this major undertook a development project of product of service in tourism, which is "Qingyou" Smart Locker. It has certain reference value for the teaching mode of designing practice that students are systematically engaged in design and development of new products. The project was mainly divided into the stages as follows. 1. Preliminary investigation and project planning. Tourism has become the most popular way of leisure for modern people. So acceleration of tourism can further promote the high-quality development of the tertiary industry. There are many problems in travel. For example, the luggage carried by tourists is burdens for them when playing. In the scenic spots now, there are usually only simple storage sites for luggage with low security and convenience. Obviously, the current tourist service facilities are unable to help tourists have the best time. In order to better develop the scenic areas and enhance the reputation of service and tourists' experience, we should vigorously develop the construction of tourism infrastructure, and promote and improve tourism services taking advantages of creating product designs. 2. Locker and design of APP. The locker is available for three different sizes of suitcases. The edges of the boxes have been specially chamfered. The upper part of each box has been designed as the arc shape while the lower part continues the traditionally rectangular design. It is convenient for people to put their luggage in. The top baffle of the box was design with the stream-line form. Cameras with different angles have been installed on the cabinet to effectively improve the security. A trash can has been placed under the locker for tourists who access the luggage to discard the carried garbage. Lockers are diverse in color and eye-catching with a visual impact. At the same time, it has been equipped with a corresponding mobile APP, which follows the concepts of easy travel. With the simple and fresh interface design, it can not only provide various tourist information and gameplay strategies, but also display the locations and usages of lockers near the scenic area for helping tourists quickly find the nearest locker. 3. Research on operation mode of the project. The smart locker is associated with the user's mobile phone to 
provide related travel services and collect data. It is the basic conditions for operating the project. A good operation model of the tourism product with good usage experience will increase satisfaction of tourists. According to the differences in tourists' knowledge and cognitive abilities, it is required to reduce the complexity of the operation increase the usability of the product as much as possible, with prominent tips at key nodes, when designing the product. To sum up, the project effectively helps students to develop their abilities of practice and teamwork. Under the premise of concern about the pain points of users, teachers and students carry out workshop-based teaching activities around the project, while arranging the mentors of rich practical experience from enterprises to participate for guidance. Eventually, the actual project has been successfully completed.

At present, foreign universities attach high attention to the abilities of project development and integrating capacity of professional knowledge for students of product design major. It is also very common for them to introduce actual projects in teaching, and to invite experts and engineers from enterprises with teachers to guide students together. Due to various reasons, only few colleges and universities in China have adopted the similar approaches now. However, the educational circle of design has gradually realized the necessity of reform on education and teaching models.

\section{The Exploration of the Teaching Model of Practice Courses of Product Design}

The employment rate of graduates majoring in product design is generally not high according to the survey of their employment situation. There are some main reasons as follows. Firstly, there is a gap between the professional knowledge and skills of the students and the requirements of employers. Secondly, the teaching goals and curriculum arrangements of the product design major have not been able to meet the actual demands of social development yet. It is supposed to be considered by product design educators that how to strengthen the teaching effects of product design and what the goals are. Now, students of product design lack innovation and practical abilities. It affects the sustainable development of China's design industry for the long term. So it is the direction of reform on design education to understand demands of the society for design talents and introduce the practice teaching of high quality. Subject to equipment, funds, technology and so on, the development and design of many products cannot be completed only with the conditions in class. It objectively leads to the difference between class teaching and actual needs of production. Especially for senior students, if the topic of the course design is not attractive enough, the negative and passive effects are likely to be made on students [5]. Product design generates business values and serves for people's lives with the actual projects operated by enterprises. Therefore, it is necessary to develop students' abilities of creative practice, and lead them to understand enterprises' actual operation of projects. As a result, students will be supplied with the environment for design and creation. At the same time, the actual project-driven teaching model also helps to achieve education for innovation and entrepreneurship, effectively improve students' professional ability, method ability and social ability (Figure 2).

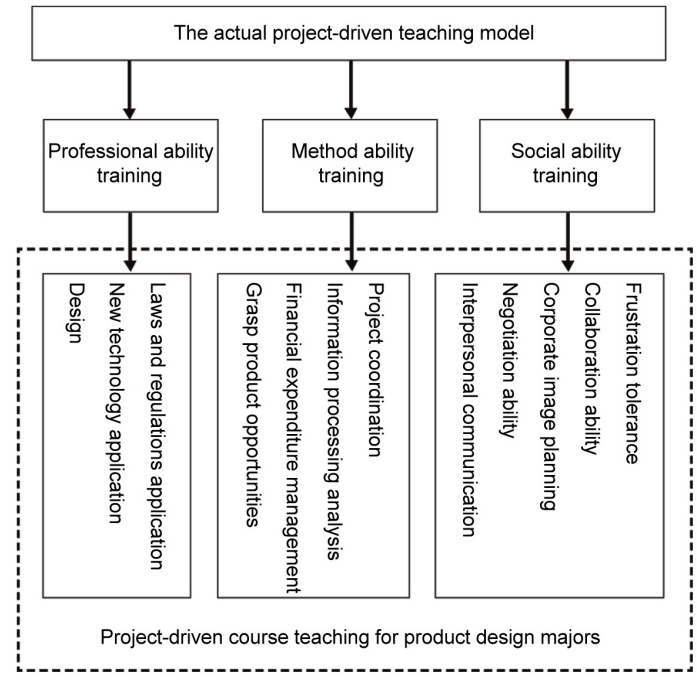

Figure 2. the actual project-driven teaching model

With the rapid development and change of design disciplines, we are required to reform the teaching models and curriculum structures in a timely manner, and to pay full attention to the foreground, new technologies and new needs of the industry. The actual projects of enterprises should be introduced into class. After formulating the specific requirements and standards, teachers will arrange projects to students and guide them to complete. Combining this major's objectives of talent training and the design of enterprises' actual projects, the practice teaching is conducted to stress the standardization, scientificalization, systematization and completeness of students' design. There are the specific implementation steps below. 1 . Group discussions on design ideas and solutions are implemented by brainstorming. 2. The members of the group are arranged to complete the investigation and classification of preliminary materials. 3. Teachers track the progress of each group and guide students to discuss. 4. Students summarize the previous work, complete sketching, computer modeling and model making to report and display the results.

With the full implementation of the two-child policy, the population of children will continue to increase in the future, followed by the great market demands for children's products. Therefore, the company's design project of children's furniture was introduced into the practice teaching of product design. Bengbu University conducted two-week training courses for the third-year students majoring in product design. By investigation, it was found that the proportion of children's products in household consumption was relatively large. As the expectations and requirements of users for children's products are getting higher and higher, enterprises should 
improve qualities of products and design service. When designing and developing children's furniture, designers should understand the behaviors, lifestyles and mental models of children, aiming at children's development of physical and mental health, and considering the spatial environment and visual forms. Compared with adults' furniture, children's furniture requires more investment in research and development of professional design. Only in this way can we ensure the safety and reliability of products and completion of functions. In addition, the design semantics should satisfy the needs of children for interest. It is major concluded as follows. 1. The principle of formal beauty is applied in the design of children's furniture. It is a kind of rational beauty that people have accumulated and evolved in long-term labor and practice. The rules of formal beauty are reflected by the constitutive form of visual elements. The basic elements of visual form are a point, line, surface, body, material and color, which produce certain beauty in form by certain combinations and changes. 2 . The form of combined body is applied. The so-called form of combined body is a new formation of multiple geometries with the modeling features of individual monomer forms, full of changes in the overall form by diversifying the combination modes. It includes as follows. (1) The combination of homogeneous geometries is a new formation of several basic forms with the same or visually similar characteristics; (2) The combination of heterogeneous geometries is a new formation of several basic forms with visual elements of different characteristics. (3) It is the serialized product form design. Since each form has its own features of expression, if we retain these features in the relevant product design and then evolve them, we can create a series of serialized forms. 3. One object is designed for multiple purposes, which mainly reflects the convertibility of functions. It brings children with a sense of freshness in utility and realizes the functional integration of children's furniture. It not only meets children's needs for functions of furniture, but also saves indoor space and reduces waste of resource. 4. The modular design method is applied. Modularity refers to a unit that can form a system, an independent function and a standard interface [6]. The focus of modularity is to scientifically and rationally formulate the elements that can be used as unit modules and establish a systematic design. It can be expanded and deformed according to the use needs. The modular design changes the dullness and boringness of children's furniture and makes the utilities of products more flexible to meet the various demands of children. For instance, furniture of different sizes is combined according to the change of children's height in the different periods. 5. The bionic shaping design, by incorporating the bionic shapes of animals and plants into the design of children's furniture, makes the product shapes lively and vital in order to meet the aesthetic demands of children. In conclusion, with the actual project of designing children's furniture, students used fully apply the knowledge of product design in practice courses. The courses were conducted in the form of workshops. With the active guidance of teachers, each group of students applied their own design concepts and methods for creative design of children's furniture. They finished sketching, 3D modeling and rendering, making physical models and so on. In this actual project, students used scientific design methods and standard design processes to design products based on the real needs of children. It is effective to cultivate design thinking and practical abilities of students with the good teaching results.

The project-driven practice teaching of product design is characterized by aiming at the demands of the industry. The instructors guide students to focus on some specific products for full investigation and design. Due to the different categories of products, the required knowledge is also different. It is conducive to prompting students to broaden their professional horizons and fully learn methods, processes and industry specifications of design. In the end, the design talents with compound abilities will be cultivated.

\section{Conclusion}

Compared with the developed countries in Europe and the United States, China's design education has the shorter history, and the education model is still developing. The education of more than 20 years for product design and industrial design has made significant contributions to society and the economy. However, with the intensified competition of international market, the requirements of related industries for design talents have further increased, so that the current teaching system and curriculum are still insufficient. In order to better improve the professional qualities of students, the reform on the teaching mode is imperative. In particular, more practice projects of enterprises should be introduced to strengthen the students' abilities of innovation, knowledge transformation, application and practice. It is necessary to strengthen the cooperation between schools and enterprises, and lead students to be engaged in frontline work referring to the development process and modes of enterprises' actual projects of product design. With actual projects, students' enthusiasm for learning is mobilized to combine their professional knowledge and skills with the demands of the market. As a result, the designing qualities of students are comprehensively improved by training their abilities to discover and solve problems, propose solutions and operate in practice. As for how to plan and arrange the curriculum in combination with design resources of actual projects, instructors are supposed to systematically design the curriculum according to the teaching requirements, and strive to achieve the curriculum of the reasonable structure, rich knowledge, and clear practice processes. Teachers should follow the training goals of design majors and combine them with the cutting-edge cases of design projects for practice teaching. In teaching, teachers update the curriculum contents and teaching methods by dynamically tracking, and strengthen students' design thinking and professional skills by practical training. 


\section{Acknowledgment}

Supported by Key projects of Anhui province universities outstanding youth talent support program (No. gxyqZD2019081), Quality Engineering Project of Anhui Higher Education (No. 2018jyxm0704), Quality Engineering Project of Bengbu Univercity (NO.2018JYXMW8)

\section{References}

1. Xianzhong, L. (2019) Probing and Practice of "Bauhaus Ideas" in Contemporary Education of Industrial Design. J. Furniture \& Interior Design., 10: 70-72.

2. Jiang, X. (2017) The Study of Product Design "Progressive Project-Based Learning" Teaching Model. (Master Thesis) Jiangnan University, China. pp. 12-15.

3. Heping, L. (2008) Thoughts on Contemporary Chinese Design Education. J. Art Education., 08: 56.

4. Sheng, W., Xinmin, P. (2018) German dual system and open teaching in vocational colleges. J. Hebei Normal University (Educational Science Edition), 03: 65-68.

5. Hao, CH. (2019) Innovation and Practice of the Product Design Teaching. J. Art \& Design., 09: 124-125.

6. Mingyang, S. (2014) Research into Automotive Modular Design. (Master Thesis) Jilin University, China. pp. 17-20. 